\author{
Aleksander Glapiak* \\ ORCID: 0000-0001-8529-4439 \\ Uniwersytet Wrocławski
}

https://doi.org/10.19195/1733-5779.33.7

\title{
Kontrola i koordynacja mechanizmów zdolności wytwórczych w świetle prawa unijnego
}

\section{JEL Classification: K2, K32}

Słowa kluczowe: mechanizmy, zdolności wytwórcze, rynek wewnętrzny, energia elektryczna, bezpieczeństwo dostaw, pomoc państwa, koordynacja

Keywords: mechanisms, capacity, internal market, electricity, security of supply, State Aid, coordination

Abstrakt: Niełatwe do przewidzenia zapotrzebowanie, względy bezpieczeństwa dostaw oraz pozostałe problemy sektora sprawiają, że sprostanie popytowi na energię elektryczną jest coraz trudniejsze. Niektóre państwa członkowskie Unii Europejskiej odpowiadają na to wyzwanie przez mechanizmy zdolności wytwórczych, którymi ingerują w rynek. Ich wprowadzenie może jednak być znacznie utrudnione, jeśli środek ten zostanie uznany za pomoc państwa. W takim wypadku mechanizm podlega kontroli zgodności z rynkiem wewnętrznym. Jej negatywny wynik może nawet wiązać się z decyzją o niezgodności środka z prawem. W kontekście tej oraz dalszych implikacji w artykule omówiono mechanizmy, które są badane w ramach kontroli zgodnie z traktatami i orzecznictwem sądów Unii, a także poddano analizie i ocenie przebieg procedury kontroli z uwzględnieniem zmian wprowadzonych pakietem prawodawczym z czerwca 2019.

\section{Capacity mechanisms control and coordination under EU law}

Abstract: Intricate forecasting of the "need for energy", the security of supply concerns, and other sectors' issues cause difficulty in meeting the demand for electricity. Some Member States of the European Union address this challenge by employing capacity mechanisms, by which they interfere in the market. Introduction of these may be entangled considerably when the measure in question is regarded as State Aid. In such a case, the mechanism is subject to a check on compliance with the internal market. Its negative outcome can result even in a decision denying lawfulness of a measure. Due to this and the following implications, this paper discusses which mechanisms are checked within the control procedure, pursuant to the Treaties and case law of the EU Courts, as

* Opiekun naukowy (Scientific Tutor) — prof. dr hab. Tadeusz Kocowski 
well as it analysing and assessing the conduct of said control procedure, concerning changes brought by the legislation package from June 2019 .

\section{Wprowadzenie - obawa o wystarczalność zasobów}

Obserwowane w ostatnich dekadach przeobrażenia sektora energetycznego stały się przyczyną poszukiwania nowych rozwiązań zdolnych sprostać współczesnym wyzwaniom ${ }^{1}$. Na tym polu rządy krajowe przyjmują między innymi środki prawne, których głównym celem jest zapewnienie bezpieczeństwa dostaw energii elektrycznej (security of supply), podstawowego w kontekście właściwego funkcjonowania państwa. Bezpieczeństwo to w obliczu wzrastających obaw o wystarczalność zasobów energetycznych może być osiągane regulacyjnymi mechanizmami nabywania zdolności wytwórczych (dalej: MZW) (capacity mechanisms). Innymi słowy jest to sposób wynagradzania dostawców za gotowość do dostarczenia zasobów. To zaś zapewnia, że wspomniana wystarczalność jest na poziomie niezbędnym do sprostania popytowi.

Dostawcy zdolności wytwórczych wynagradzani są w ten sposób ze środków pochodzących od państwa, co może być osiąganiem korzyści gospodarczej. Jeśli mechanizm, zgodnie z którym wypłaca się to wynagrodzenie, jest podstawą udzielania subsydium czy pomocy albo podobnego środka zakłócającego konkurencję na rynku wewnętrznym, to co do zasady jest niedozwolony w unijnym porządku prawnym, o czym mówi art. 107 ust. 1 Traktatu o funkcjonowaniu Unii Europejskiej (dalej: TFUE) ${ }^{2}$. W tym układzie ów środek będzie zakwalifikowany jako pomoc państwa (State aid) z punktu widzenia prawa unijnego.

$\mathrm{Z}$ tego względu rząd, który zamierza wprowadzić pomoc państwa w postaci MZW w celu sprostania obawom o wystarczalność zasobów, powinien zgłosić ten środek do Komisji Europejskiej (dalej: Komisja). Organ ten, zgodnie z art. 108 TFUE, jako jedyny w systemie unijnym ma kompetencje kontrolne w zakresie pomocy państwa. Zgłoszony środek analizowany jest pod kątem zgodności z rynkiem wewnętrznym. Wynikiem tego postępowania, w którym państwo członkowskie występuje w roli kontrolowanego, może być decyzja stwierdzająca zgodność pomocy (a zatem jej legalność w rozumieniu art. 107). Jeśli zaś pomoc została przyznana bezprawnie, musi być zwrócona wraz z odsetkami państwu, które ją wypłaciło, aby wrócić do stanu sprzed otrzymania pomocy.

1 Zob. Sprawozdanie końcowe Komisji z badania sektorowego dotyczącego mechanizmów zapewniających zdolności wytwórcze, COM(2016) 752 final, EUR-Lex 52016DC0752, sekcja 2.2 (dalej: sprawozdanie z 2016); L. Hancher, Ch. Riechmann, Capacity Mechanisms and Auctions, [w:] State aid and the energy sector, red. L. Hancher, A. de Hauteclocque, F.M. Salerno, Oxford 2018, s. 150-152; F.E. González-Díaz, EU Policy on Capacity Mechanisms, [w:] Capacity Mechanisms in the EU Energy Market: law, politics and economics, red. L. Hancher, A. de Hauteclocque, M. Sadowska, Oxford 2015, s. 3-7.

2 Dz. Urz. UE C 202 z dnia 7 czerwca 2016, s. 1. 
Należy jednak podkreślić, że w postępowaniu kontrolnym badane są tylko te mechanizmy, które spełniają traktatowe kryteria pomocy państwa z art. 107 ust. 1, co dla państw członkowskich ma niebagatelne znaczenie. Znacznie korzystniej stworzyć bowiem środek, który nie podlegałby obowiązkowemu badaniu przez Komisję, a zatem taki, który nie byłby pomocą państwa. Nie ulega przy tym wątpliwości, że obserwowana zmiana stanowiska Komisji w sprawie tego zakresu przedmiotowego, a także dążenia państw członkowskich do zacieśnienia współpracy w sektorze energetycznym spowodowały stopniową ewolucję regulacji MZW. Te procesy nasuwają pytania o aktualny kształt procedury kontroli, jej zakres przedmiotowy, a także o kryteria stosowane przez Komisję. Zauważyć też należy, że obserwowana ewolucja jest odpowiedzią na wcześniejsze wskazania doktryny zwłaszcza w kontekście postulatu koordynacji regulacji sektorowej na poziomie unijnym.

Celem niniejszego opracowania jest zbadanie zmian, jakie zaszły w postępowaniu prowadzonym przez Komisję, a wprowadzone zostały rozporządzeniem Paramentu Europejskiego i Rady (UE) 2019/943 w sprawie rynku wewnętrznego energii elektrycznej (dalej: rozporządzenie 2019/943) ${ }^{3}$ oraz przedstawienie aktualnego kształtu postępowania kontrolnego wraz z oceną obowiązującej regulacji koordynującej mechanizmy wdrażane w poszczególnych państwach.

Wielość i kompleksowość wspomnianych zmian w podejściu Komisji do MZW sprawia, że w pracy skupiono się głównie na aktualnym stanie prawnym. Zostanie on zanalizowany metodą doktrynalną na podstawie orzeczeń sądów Unii, uwag w literaturze przedmiotu oraz w dokumentów roboczych Komisji.

\section{Zakres przedmiotowy kontroli}

W obowiązującym stanie prawnym MZW traktowane są zwykle jako środki stanowiące pomoc państwa, a jako takie zgłaszane są przez państwo członkowskie i badane w postępowaniu kontrolnym Komisji zgodnie z art. 108 TFUE $^{4}$. Należy przy tym wskazać, kiedy MZW w ogóle należą do kategorii pomocy państwa w myśl art. 107 ust. 1. Zawarte w przywołanej regulacji kryteria zostały zinterpretowane przez Trybunał Sprawiedliwości Unii Europejskiej (dalej: TSUE) następująco:

Po pierwsze, musi to być interwencja państwa lub za pośrednictwem zasobów państwa. Po drugie, interwencja ta musi być w stanie wpłynąć na wymianę handlową między państwami człon-

${ }^{3}$ Rozporządzenia Parlamentu Europejskiego i Rady (UE) 2019/943 z dnia 5 czerwca 2019 roku w sprawie rynku wewnętrznego energii elektrycznej, Dz. Urz. UE L 158 z dnia 14 czerwca 2019, s. 54.

${ }^{4}$ Zob. decyzja Komisji w sprawie Irlandia, obowiązek użyteczności publicznej w związku z nową zdolnością wytwórczą energii elektrycznej dla bezpieczeństwa dostaw, N475/2003 (2003), C(2003)4488fin; decyzja Komisji w sprawie Słowenia, wsparcie produkcji energii elektrycznej z odnawialnych źródeł energii i w instalacjach kogeneracyjnych, N354/2009 (2009), C(2009)8353, w których MZW nie były uznawane za pomoc państwa. 
kowskimi. Po trzecie, musi przyznawać beneficjentowi selektywną korzyść. Po czwarte, musi ona zakłócać konkurencję lub grozić jej zakłóceniem ${ }^{5}$.

Pierwsze kryterium (transfer środków państwa) w wypadku MZW pozostawia pewne pole do dyskusji nad relacją wynagrodzenia ustanawianego zgodnie z mechanizmem a pomocą państwa. Drugi warunek wydaje się niewątpliwie spełniony, jako że wprowadzenie mechanizmu w państwie A będzie wywoływać skutki we wzajemnie połączonym państwie B niedysponującym mechanizmem, między innymi przez potencjalny odpływ inwestorów na rynku energetycznym ${ }^{6}$. Trzecie kryterium (połączone korzyść gospodarcza i selektywność) może być także kwestią sporną w wypadku MZW, jako że dostawcy zdolności wytwórczych mogą na przykład być wynagradzani za usługę użyteczności publicznej (public service obligation, PSO), a zatem nie osiągają korzyści gospodarczej, jedynie zaś otrzymują wynagrodzenie za świadczoną usługę. Czwarty warunek w opinii Komisji jest spełniony ${ }^{7}$, co pozostawia jedynie dwie wspomniane drogi uniknięcia kategorii pomocy państwa przy konstrukcji (i aplikacji) MZW. Są to interwencja państwowa lub za pośrednictwem zasobów państwa oraz selektywność i korzyść.

\subsection{Kryteria: korzyść gospodarcza i selektywność}

Pierwszym sposobem na zaprojektowanie mechanizmu niebędącego zarazem pomocą państwa jest niespełnienie przesłanki selektywnej korzyści gospodarczej (selective economic advantage). Korzyścią ekonomiczną, o której mowa

jest każda korzyść gospodarcza, jakiej przedsiębiorstwo nie uzyskałoby w normalnych warunkach rynkowych, tzn. bez interwencji państwa. Z korzyścią mamy do czynienia wtedy, gdy sytuacja finansowa przedsiębiorstwa ulega polepszeniu w wyniku bezpośredniego działania państwa, a nie na skutek gry rynkowej ${ }^{8}$.

Warto przy tym nadmienić, że korzyść ta może mieć charakter zarówno pozytywny, jak i negatywny ${ }^{9}$ (jak zmniejszenie obciążeń nałożonych na przedsiębior-

${ }^{5}$ Wyrok TSUE w sprawie Komisja v FIH, C-579/16 P, ECLI:EU:C:2018:159, pkt 43; zob. też wyrok TSUE w sprawie Komisja v World Duty Free Group i in., C-20/15 P i C-21/15 P, ECLI:EU:C:2016:981, pkt 53.

${ }^{6}$ Od samego początku nie było zgody na domyślny udział MZW w rynkach wszystkich państw członkowskich, zob. L. Hancher, Ch. Riechmann, op. cit., s. 152.

7 Zob. ust. 3.9.6. komunikatu Komisji - Wytyczne w sprawie pomocy państwa na ochronę środowiska i cele związane z energią w latach 2014-2020, EUR-Lex 52014XC0628(01).

8 Opinia Rzecznika Generalnego Camposa Sáncheza-Bordony w sprawie Georgsmarienhütte GmbH v RFN, C-135/16, ECLI:EU:C:2018:120, pkt 78; zob. wyrok ETS w sprawie Hiszpania $v$ Komisja, C-342/96, CLI:EU:C:1999:210, pkt 41.

9 Zob. wyrok ETS w sprawie Adria-Wien Pipeline i Wietersdorfer v Peggauer Zementwerke, C-143/99, ECLI:EU:C:2001:598, pkt38; wyrok ETS w sprawie Heiser, C-172/03, ECLI:EU:C:2005:130, pkt 36 .

Studenckie Prace Prawnicze, Administratywistyczne

i Ekonomiczne 33, 2020

(C) for this edition by CNS 
stwa) czy nawet „pośredni”10. Aby jednak taka korzyść musiała zostać zgłoszona przez państwo członkowskie i poddana kontroli Komisji, dotyczyć powinna konkretnych przedsiębiorstw albo produkcji konkretnych produktów, a zatem nie być przyznana w sposób generalny (kryterium selektywności).

Przeniesienie tych spostrzeżeń na konstrukcję i aplikację MZW powodowałoby, że albo mechanizmy były podstawą wynagradzania wszystkich podmiotów rynku, albo pomoc zgodnie z nimi udzielona nie mogłaby stanowić gospodarczej korzyści. Obecność tej korzyści można jednak wykluczyć, jeśli środek spełnia wszystkie warunki orzeczenia w sprawie Altmark $^{11}$. Są nimi: wyraźnie określone zobowiązanie przedsiębiorstwa do świadczenia usługi w interesie ogólnym (services of general economic interest, SGEI), obiektywny i transparentny sposób ustalania rekompensaty, kompensowanie nieprzekraczające całości lub części kosztów świadczenia usługi (wraz z rozsądnym zyskiem i przychodami związanymi z wypełnieniem zobowiązania), a także analizowanie tych kosztów deklarowanych przez przedsiębiorstwo w porównaniu z przeciętnymi wydatkami ponoszonymi przez prawidłowo zarządzane przedsiębiorstwo (chyba że beneficjent został wybrany w ramach procedury zamówień publicznych). Za zgodne z tym testem zostały w przeszłości uznane mechanizmy irlandzki i słoweński ${ }^{12}$.

Mimo relatywnej popularności testu Altmark (zwłaszcza że państwom członkowskim przysługuje uprawnienie do określania zakresu świadczenia usług w interesie ogólnym ${ }^{13}$ ) spełnienie jego przesłanek nie jest łatwe. Gdyby właśnie wspomniany test nie był wypełniony, usługa uży teczności publicznej może być jeszcze uznana za dopuszczalną na gruncie art. 106 ust. 2 TFUE, na co wielokrotnie wskazywał Trybunał ${ }^{14}$. O ile jednak z początku Komisja, zatwierdzając mechanizmy państw członkowskich, powoływała się na tę przesłankę ${ }^{15}$, o tyle począwszy od sprawy mechanizmu zgłoszonego w roku 2009 przez władze łotewskie wynagrodzenie przyznawane na podstawie MZW traktowane jest przez Komisję jako

10 Zob. wyrok ETS w sprawie Niemcy v Komisja, C-156/98, ECLI:EU:C:2000:467, pkt 25-27; wyrok TSUE w sprawach Bouygues, C-399/10 P i C-401/10 P, ECLI:EU:C:2013:175, p. 108.

11 Wyrok ETS w sprawie Altmark Trans, C-280/00, ECLI:EU:C:2003:415, szczególnie pkt 88-94.

12 Zob. przypis 4.

13 Dyskrecjonalna władza państw jest potwierdzona zarówno w TFUE, zob. art. 14, Protokó1 (nr 26) w sprawie usług świadczonych w interesie ogólnym, jak i w orzecznictwie, zob. wyrok TSUE w sprawie $A B$,Achema” v VKEKK, C-706/17, ECLI:EU:C:2019:407, p. 104.

14 Zob. wyrok TSUE w sprawie Viasat Broadcasting UKvKomisja, C-660/15 P, ECLI:EU:C:2017:178, pkt 34; wyrok TSUE w sprawie $A B$,Achema” $v$ VKEKK, pkt 102.

15 Zob. decyzja Komisji w sprawie Hiszpania, preferencyjne wykorzystywanie na rzecz elektrowni używających rodzimego węgla, N178/2010 (2010), C(2010)4499; E. Righini, J.C. González Fernández, Capacity Mechanisms and State Aid: Between PSOs, Market Liberalisation, and Security of Supply, „Journal of European Competition Law \& Practice” 2016, nr 7 (10), s. 668-669. 
korzyść gospodarcza, nie zaś rekompensata za świadczenie usługi w ogólnym interesie ${ }^{16}$.

Ponadto aby droga ta umożliwiała państwu członkowskiemu pominięcie zgłoszenia środka, potrzebne jest jeszcze spełnienie dodatkowego kryterium. Wymaga ono, by wynagrodzenie otrzymywane na podstawie MZW przez dostawców zdolności wytwórczych nie było zaledwie dodatkiem do i tak osiąganych dochodów ze sprzedaży energii elektrycznej. To zaś wydaje się zmuszać przedsiębiorców objętych mechanizmem do wyłącznego czerpania zysków z tego środka ${ }^{17}$.

\subsection{Kryterium: finansowanie mechanizmu}

Innym sposobem wprowadzenia mechanizmu wynagradzania zdolności wytwórczych niebędącego pomocą państwa jest ustanowienie przez państwo odmiennego finansowania tego mechanizmu. Kryterium to, pozostając w związku z pierwszym warunkiem art. 107 ust. 1 TFUE, wyraża się w państwowym pochodzeniu środków. Innymi słowy konieczne jest, by korzyści przewidziane mechanizmem zostały „przyznane bezpośrednio lub pośrednio z zasobów państwowych oraz, po drugie, aby można je było przypisać państwu" 18 . Oba warunki mają charakter kumulatywny. W rezultacie środek niespełniający przynajmniej jednego z nich nie może być uznany za interwencję państwa lub pomoc przy użyciu zasobów państwa, a w rezultacie za pomoc państwa.

Przyznanie korzyści z zasobów państwa w sposób bezpośredni i pośredni jest konieczne do uznania środka za pomoc w rozumieniu art. 107 ust. 1 TFUE. W kontekście tego warunku literatura powołuje się często na precedensowe orzeczenie w sprawie PreussenElektra ${ }^{19}$. Orzecznictwo TSUE interpretuje jako pomoc państwa jedynie korzyści finansowane bezpośrednio przez państwo oraz przez podmioty prywatne i publiczne desygnowane albo utworzone przez państwo $^{20}$. Miarą państwowego pochodzenia środków nie musi być stałe wchodzenie ich w skład skarbu państwa, lecz wystarczy rzeczywisty do nich dostęp, choćby

16 Decyzja Komisji w sprawie Łotwa, oferta przetargowa dotycząca pomocy dla nowych zdolności wytwórczych energii elektrycznej N675/2009 (2010), C(2010)4146.

17 Zob. sprawozdanie z 2016, sekcja 4.

18 Wyrok TSUE w sprawie Association Vent De Colère! i inni, C-262/12, ECLI:EU:C:2013:851, pkt 16; zob. także wyrok ETS w sprawie Francja v Komisja, C-482/99, ECLI:EU:C:2002:294, pkt 24; oraz wyrok TSUE w sprawie $A B$,Achema” $v V K E K K$, pkt 47.

19 Wyrok ETS w sprawie PreussenElektra AG v Schhleswag AG, C-379/98 ECLI:EU:C:2001:160; zob. między innymi P. Nicolaides et al., The Concept of State Aid, [w:] iidem, State Aid Policy in the European Community. Principles and Practice, Alphen aan den Rijn 2008, s. 12n.; L. Hancher, Capacity Mechanisms and State Aid Control, [w:] Capacity Mechanisms in the EU Energy..., s. 167.

20 Zob. wyrok ETS w sprawach Sloman Neptun, C-72/91 i C-73/91, ECLI:EU:C:1993:97, pkt 19; wyrok ETS w sprawie Ecotrade, C-200/97, ECLI:EU:C:1998:579, pkt 35; wyrok TSUE w sprawie ENEA, C-329/15, ECLI:EU:C:2017:671, pkt 23. 
przez sprawowanie stałej kontroli publicznej nad środkami finansowymi ${ }^{21}$. Trybunał orzekł, że również wprowadzenie obowiązku zakupu energii pochodzącej z kogeneracji może być swoistą „pomocą” państwa mimo braku przepływu zasobów państwowych ${ }^{22}$. Racje tego podejścia wymagają jednak rozróżnienia - gdy ten sam obowiązek jest nałożony na przedsiębiorstwo z większościowym udziałem prywatnym ${ }^{23}$, które nie jest uprawnione do dysponowania środkami państwa, lecz kupuje energię z funduszy własnych (prywatnych), nie stanowi to korzyści w rozumieniu art. 107 ust. 1 TFUE ${ }^{24}$.

Gdy idzie zaś o warunek przypisywalności środka państwu, w wypadku MZW będzie on zasadniczo spełniany za każdym razem, przy czym państwa członkowskie zwykle przyznają wprost albo nie podważają oczywistego państwowego pochodzenia wprowadzonego środka ${ }^{25}$. Jak wynika z utrwalonego orzecznictwa TSUE, test przypisania środka państwu ogranicza się do sprawdzenia, czy władze państwowe były zaangażowane (uczestniczyły) w ustanowieniu mechanizmu ${ }^{26}$.

Mimo tych wyjątków państwa członkowskie ze względu na pewność prawa powinny bardzo ostrożnie decydować o niezgłaszaniu MZW w kontekście art. 108 ust. 3 i czynić to, jedynie gdy nie ma cienia wątpliwości co do natury mechanizmu $^{27}$. Nie jest też pewne, jak Komisja oceniłaby podobny zabieg, mając na względzie podnoszone przez ten organ kontroli kryterium niewiązania się środka z udziałem państwa ${ }^{28}$.

${ }^{21}$ Zob. wyrok ETS w sprawie Francja v Komisja, pkt 37; wyrok ETS w sprawie Essent Netwerk Noord, C-206/06, ECLI:EU:C:2008:413, pkt 70; wyrok TSUE w sprawie Association Vent De Colère! i inni, pkt 21.

22 Zob. wyrok TSUE w sprawie ENEA, pkt 24; wyrok TSUE w sprawie Niemcy v Komisja, C-405/16 P, ECLI:EU:C:2019:268, pkt 56.

${ }^{23}$ Należy odnotować, że proporcje udziałów w przedsiębiorstwie nie będą także kryterium decydującym. Podmiot prywatny może być bowiem wyznaczony albo utworzony przez państwo, a zarządzając zasobami państwowymi, znajduje się w zakresie art. 107 ust. 1 TFUE.

${ }^{24}$ Zob. wyrok TSUE w sprawie ENEA, pkt 26; wyrok TFUE w sprawie Niemcy v Komisja, C-405/16 P, pkt 59.

${ }^{25}$ Zob. wyrok TSUE w sprawie $A B$ „Achema” $v$ VKEKK, pkt 49; wyrok TSUE w sprawie Association Vent De Colère! i inni, pkt 18; wyrok TSUE w sprawie ENEA, pkt 22.

26 Zob. wyrok TSUE w sprawie Association Vent De Colère! i inni, pkt 17; wyrok TSUE w sprawie ENEA, pkt 21; wyrok TSUE w sprawie Niemcy v Komisja, C-405/16 P, pkt 49; otwarty katalog przesłanek mogących wskazywać na państwowe pochodzenie środka został wskazany w wyroku ETS w sprawie Francja v Komisja (Stardust), C-482/99, ECLI:EU:C:2002:294, pkt $55-56$.

27 Szczególnie w kontekście tendencji do upatrywania w MZW pomocy państwa, zob. między innymi sprawozdanie z 2016, sekcja 1.

28 Oraz pozostałego, dotyczącego zapewniania bezpieczeństwa dostaw energii elektrycznej. Zob. sprawozdanie z 2016, sekcja 4. 


\section{Postępowanie kontrolne - przebieg i zasady oceny}

Tak ukształtowany zakres przedmiotowy postępowania kontrolnego wpłynął na postrzeganie mechanizmów jako środków zasadniczo stanowiących pomoc państwa. Zmiana ta skutkowała oceną Komisji opartą już nie tylko na sprawdzeniu oczywistego błędu w stosowaniu art. 106 ust. 2 (jak w początkowych sprawach badania mechanizmów - w Słowenii czy Irlandii $\left.{ }^{29}\right)$, lecz na znacznie dalej idącym postępowaniu kontrolnym $\mathrm{z}$ art. 108.

W polskiej doktrynie prawa administracyjnego kontrolę określa się jako obserwację $\mathrm{i}$ analizę stanu istniejącego i porównanie go ze stanem postulowanym. Wynikiem zaś kontroli jest ustalenie zakresu i przyczyn zauważonych rozbieżności ${ }^{30}$. W wypadku kontroli MZW, która dokonywana jest zgodnie $\mathrm{z}$ art. 108 TFUE, podmiotem kontrolowanym jest państwo członkowskie, a konkretnie podmiot wskazany na zasadzie autonomii instytucjonalnej. Komisja zaś jest podmiotem kontrolującym, badając mechanizmy planowane przez regulatora krajowego, a będące pomocą państwa.

\subsection{Zasady oceny - kryteria kontroli}

Przed wejściem w życie rozporządzenia 2019/943 kontrola wspomnianych mechanizmów była dokonywana jedynie przez pryzmat wspólnych zasad wskazanych w Wytycznych w sprawie pomocy państwa na ochronę środowiska i cele związanych z energią w latach 2014-2020 (dalej: Wytyczne 2014-2020) ${ }^{31}$. W sekcji 3.9 dokumentu Komisja nakreśliła za ich pomocą ogólny kierunek (stan postulowany), w jaki MZW powinny być konstruowane. Zdatność mechanizmów do jego urzeczywistnienia jest zatem oceniana przy użyciu korespondujących kryteriów - ich osiągnięcie pozwala na spełnienie zasad.

Środki takie jak MZW są oceniane pod kątem zgodności z rynkiem wewnętrznym na podstawie następujących zasad ${ }^{32}$ :

— przeznaczenie środka na zapobieganie krótko- i długoterminowym obawom o wystarczalność zasobów (co jest przedmiotem wspólnego zainteresowania wywiedzionym $z$ art. 107 ust. 3 TFUE);

— konieczność interwencji państwa; wiąże się ona z oceną alternatyw jako niewystarczających do osiągnięcia celu;

29 Zob. decyzje Komisji: N475/2003 (2003), C(2003)4488fin; N354/2009 (2009), C(2009)8353.

30 Zob. K. Horubski et al., Podstawowe pojęcia publicznego prawa gospodarczego, [w:] System prawa administracyjnego, t. 8a. Prawo publiczne gospodarcze, red. Hauser R. et al., Warszawa 2018, Nb. 764.

31 Wytyczne (na dzień 17 lutego 2020) są przedmiotem procedury kontroli przydatności (Fitness check).

32 Wytyczne 2014-2020, pkt 27; zgodne jest to z założeniami komunikatu Komisji — Unowocześnienie unijnej polityki w dziedzinie pomocy państwa, COM(2012) 209 final, EUR-Lex 52012DC0209, pkt 18 (dalej: Unowocześnienie pomocy państwa). 
— adekwatność środka, czyli wynagradzanie jedynie dostępności producentów i otwartość na wszystkie typy generacji ${ }^{33}$;

— efekt zachęty, a zatem szczególnie podkreślane przez Komisję ${ }^{34}$ kształtowanie zachowań, które byłoby niemożliwe w braku mechanizmu;

— proporcjonalność pomocy zapewniająca zasadną stopę zwrotu i zapobiegająca osiąganiu niespodziewanego zysku;

- unikanie nadmiernego negatywnego wpływu na konkurencję i handel między państwami członkowskimi, głównie przez zwiększanie liczby producentów energii, promowanie różnorodności dostawców zdolności wytwórczych ze szczególnym uwzględnieniem tych, które najmniej zakłócają rynek (odpowiedź strony popytowej) czy składowanie energii ${ }^{35}$;

— transparentność środka.

Niemniej zdaniem Komisji dotychczasowa unijna regulacja MZW była nie dość klarowna i skuteczna, by sprostać nowym wyzwaniom rynku energii ${ }^{36}$. Wytyczne 2014-2020 ponadto należą wyłącznie do soft law („miękkie prawo”), a skoro są tak szczegółową interpretacją postanowień traktatowych o pomocy państwa, ich rola $\mathrm{w}$ procesie stosowania prawa wzbudza wątpliwości ${ }^{37}$. Jako rozwiązanie tego problemu zapewniające spójność i skuteczne stosowanie prawa względem omawianych mechanizmów przyjęto art. 21 ust. 7, art. 21 ust. 8 oraz art. 22 ust. 1-4, art. 26 rozporządzenia 2019/943. Określają one zasady konstrukcji, które częściowo odwołują się do założeń Wytycznych 2014-2020, zarazem ich nie derogując. Wyliczone tu, niewiążące dla państw członkowskich, zasady w wypadku kolizji $\mathrm{z}$ nowym katalogiem są lex inferior oraz lex prior.

Określone rozporządzeniem 2019/943 zasady konstrukcji są podzielone zgodnie $\mathrm{z}$ rozróżnieniem mechanizmów na preferowane przez Komisję rezerwy strategiczne (o stosunkowo niewielkim wpływie na kształtowanie cen ${ }^{38}$ ) ze szczególnymi wymogami w art. 22 ust. 2 oraz na pozostałe mechanizmy - ust. 3. Obu kategorii zaś dotyczą wspólne zasady projektowania wymienione w art. 22 ust. 1: czasowość (nie dłużej niż 10 lat — art. 21 ust. 8); niedoprowadzanie do nadmiernych zakłóceń rynku; transparentny, niedyskryminacyjny, konkurencyjny wybór dostawców zdolności wytwórczych; tworzenie zachęt dla dostawców zdolności wytwórczych do dostępności w czasie spodziewanego przeciążenia systemu;

33 Wytyczne 2014-2020, sekcja 3.9.3.

34 Unowocześnienie pomocy państwa, pkt 12 i 18.

35 Wytyczne 2014-2020, pkt 232.

36 Zob. projekt rozporządzenia Parlamentu Europejskiego i Rady w sprawie rynku wewnętrznego energii elektrycznej, COM(2016) 861 final, EUR-Lex 52018XC0719(01), EUR-Lex 52016PC0861, s. 15 .

37 Zob. K. Huhta, Capacity Mechanisms in EU Energy Law, Alphen aan den Rijn 2019, s. 126.

38 Zob. F.E. González-Díaz, op. cit., s. 11. Por. analizę ekonomiczną rezerw w N. Hary, V. Rious, M. Saguan, The electricity generation adequacy problem: Assessing dynamic effects of capacity remuneration mechanisms, „Energy Policy” 2016, nr 91, zwł. s. 123-124. 
ustalanie wynagrodzenia przez konkurencyjny proces; wprowadzenie technicznych wymogów uczestnictwa dostawców zdolności wytwórczych przed procesem ich wyboru; otwartość na różne zdolności zainstalowane nie tylko w segmencie przedprodukcyjnym, zwłaszcza odpowiedź strony popytowej i składowanie energii; stosowanie odpowiednich sankcji dla dostawców, którzy w czasie przeciążenia systemu energetycznego nie byli dostępni. Echem przesłanki dotyczącej konieczności interwencji państwa (art. 21 ust. 1) wydaje się wymaganie, by konstrukcja MZW pozwalała na ich efektywne administracyjne wycofywanie w warunkach art. 21 ust. 7, podczas gdy refleksem polityki klimatycznej UE są wymagania w zakresie limitów emisji dwutlenku węgla (art. 22 ust. 4). Państwa członkowskie podczas projektowania mechanizmu czy określania ilości nabywanych przez nie zdolności wytwórczych powinny uwzględniać normę niezawodności ustanowioną w zgodzie z art. 25. Natomiast wielokrotnie podkreślana wartość transgranicznego obrotu znalazła odzwierciedlenie w ostatniej wspólnej zasadzie, którą jest otwartość na zdolności wytwórcze pochodzące od dostawców z pozostałych państw członkowskich i równorzędne ich traktowanie w procesie konkurencyjnym z krajowymi zdolnościami ${ }^{39}$. Wprowadzający ją art. 26 wskazuje też warunki takiego udziału.

Zasady te znajdują zastosowanie w postępowaniu kontrolnym ustanowionym traktatowo (art. 108 TFUE) oraz rozwiniętym w rozporządzeniu Rady Europejskiej 2015/1589 ustanawiającym szczegółowe zasady stosowania art. 108 TFUE (dalej: rozporządzenie 2015/1589) ${ }^{40}$.

\subsection{Postępowanie wobec pomocy państwa}

Sam początek postępowania, choć co do zasady nieobowiązkowy ${ }^{41}$, jest prenotyfikacją środka ${ }^{42}$. Przybiera ona formę nieformalnego i poufnego kontaktu między państwem członkowskim a Komisją, która ma służyć przede wszystkim dostarczeniu potrzebnych informacji zespołowi wyznaczonemu do dokonania kontroli środka. Prenotyfikacyjny kontakt następujący za każdym razem, gdy

39 Zob. pkt 2 preambuły rozporządzenia 2019/943; sekcje 6.1 i 6.4 sprawozdania z 2016; B. Tennbakk et al., Framework for cross-border participation in capacity mechanisms, Luksemburg 2014, zwł. s. 125-126; M. Capeda, Assessing cross-border integration of capacity mechanisms in coupled electricity markets, „Energy Policy” 2018, nr 119, s. 28-29.

40 Dz. Urz. UE L 248 z dnia 24 września 2015, s. 9.

41 Obligatoryjność kontaktu prenotyfikacyjnego zachodzi w wypadku uruchomienia usprawnionej procedury (streamlined procedure), zob. sekcję 6.2. komunikatu Komisji z dnia 16 lipca 2018 - Kodeks najlepszych praktyk dotyczących przebiegu postępowania w zakresie kontroli pomocy państwa, C(2018) 4412 final, EUR-Lex 52018XC0719(01), (dalej: Kodeks praktyk).

42 Zob. F. Mazzocchi, The Procedures before the Commission, [w:] Competition and State Aid — An Analysis of the EU Practice, red. A. Santa Maria, Alphen aan den Rijn 2015, s. 113. 
państwo członkowskie go zażąda ${ }^{43}$, pozwala też na wcześniejsze wprowadzenie zmian przez notyfikujące państwo.

Formalnym zaś zainicjowaniem postępowania jest co do zasady zgłoszenie pomocy państwa (notion of State aid) przez państwo członkowskie (stronę postępowania uprzywilejowaną ze względu na komunikację z organem kontrolnym, Komisją ${ }^{44} \mathrm{i}$ dysponującą prawem do obrony ${ }^{45}$ ). Dotyczyć ono może zarówno środków, o których mowa w art. 106 ust. $2^{46}$, art. 107 ust. 2 oraz art. 107 ust. 3 TFUE, z wyłączeniem wyjątków uznanych ex lege za zgodne z rynkiem wewnętrznym ${ }^{47}$. Zgłoszenie to musi być dokonane w ramach czasowych, które pozwolą Komisji na przedstawienie swoich uwag (art. 108 ust. 3 TFUE). Następne stadia, bardzo oszczędnie ujęte w Traktacie, rozwinięte zostały na mocy art. 109 TFUE w rozporządzeniu 2015/1589. Dopełnia ono też samo pojęcie zgłoszenia pomocy państwa przez wprowadzenie kategorii ,zgłoszenia kompletnego”, w ramach którego państwo członkowskie dostarcza Komisji wszystkich koniecznych informacji mających posłużyć do wydania decyzji kończącej wszczęte postępowanie (art. 2 ust. 2 rozporządzenia 2015/1589).

Komisja bezzwłocznie rozpoczyna stadium nazywane badaniem wstępnym (preliminary examination), które może być zakończone jednym z trzech rozstrzygnięć w formie decyzji:

— ustaleniem, że środek nie stanowi pomocy państwa (co może zajść między innymi wtedy, gdy państwo zgłasza środek w celu upewniania się co do jego charakteru);

— stwierdzeniem zgodności środka z rynkiem wewnętrznym, możliwym jedynie przy nieistnieniu wątpliwości (,decyzja o niewnoszeniu zastrzeżeń”);

43 Kodeks praktyk, s. 5.

44 Zob. wyrok Sądu Pierwszej Instancji w sprawie Technische Glaswerke Ilmenau v Komisja, T-198/01, ECLI:EU:T:2004:222, pkt 61 (odwolanie od tego orzeczenia zostało oddalone); opinia Rzecznika Generalnego Evgeniego Tancheva w sprawie Komisja v Gmina Miasto Gdynia i Port Lotniczy Gdynia Kosakowo, C-56/18 P, ECLI:EU:C:2019:569, pkt 25.

45 Zob. wyrok TSUE w sprawie Technische Glaswerke Ilmenau, C-139/07 P, ECLI:EU:C:2010:376, pkt 57.

46 O możliwości takiego ukształtowania MZW mowa była w części 2.1.

47 Art. 107 ust. 3 TFUE zawiera niewyczerpującą listę wyjątków, jednak o ich zachodzeniu in concreto decyduje Komisja; odmiennie natomiast przedstawia się kwestia pomocy będącej przedmiotem rozporządzenia Komisji nr 651/2014 z dnia 17 czerwca 2014 roku uznającego niektóre rodzaje pomocy za zgodne z rynkiem wewnętrznym w zastosowaniu art. 107 i 108 TFUE (Dz. Urz. UE L 187 z dnia 26 czerwca 2014) — w jej przypadku pojawia się założenie zgodności środka z rynkiem wewnętrznym, które później może zostać obalone; podobnie też w wypadku pomocy bagatelnej regulowanej przez rozporządzenie Komisji nr 1407/2013 z dnia 18 grudnia 2013 roku w sprawie stosowania art. 107 i 108 Traktatu o funkcjonowaniu Unii Europejskiej do pomocy de minimis (Dz. Urz. UE L 352 z dnia 24 grudnia 2013). Niemniej oba rozporządzenia nie znajdują zastosowania dla MZW, choć z różnych względów (zob. art. 13a rozporządzenia 651/2014 oraz art. 3 ust. 2 rozporządzenia 1407/2013). 
— wszczęciem formalnej procedury dochodzenia (art. 4 ust. 2, 3 i 4 rozporządzenia 2015/1589).

Bieg terminu na wydanie rozstrzygnięcia zamykającego badanie wstępne jest uzależniony od daty otrzymania „zgłoszenia kompletnego” i wynosi dwa miesiące. Okres za obopólną zgodą stron może zostać wydłużony, a także jednostronnie skrócony przez Komisję. W wypadku bezskutecznego upływu terminu pomoc nominalnie zostaje uznana za zgodną z rynkiem wewnętrznym, niemniej państwo członkowskie pragnące ją wdrożyć musi wcześniej wysłać zgłoszenie. Komisja w odpowiedzi może wydać któreś z wymienionych rozstrzygnięć w ciągu piętnastu dni roboczych od daty otrzymania zgłoszenia (art. 4 ust. 6$)^{48}$.

Wskazany przebieg ujawnia relatywną szybkość postępowania, które w wypadku odpowiednio przygotowanego kompletnego zgłoszenia może trwać jedynie dwa miesiące (pod warunkiem niepodjęcia decyzji o wszczęciu formalnej procedury dochodzenia). W tej kwestii godny podkreślenia jest akcent ${ }^{49}$ położony przez Komisję na prenotyfikację jako sposób skrócenia formalnego postępowania i potencjalnego wyjaśnienia wszystkich wątpliwości w stadium badania wstępnego. Warto wspomnieć, że na etapie badania wstępnego stronami są wyłącznie państwo członkowskie oraz Komisja.

Jeśli została wydana decyzja wszczynająca (art. 4 ust. 4), tuż po badaniu wstępnym następuje kolejne stadium postępowania, którego odmienność niejednokrotnie była podkreślana $\mathrm{w}$ orzecznictwie TSUE ${ }^{50}$ - formalna procedura dochodzenia (formal investigation procedure). Decyzja wszczynająca wzywa zarazem państwo-stronę, a także inne „zainteresowane strony” do przedstawienia uwag, które następnie zostają przesłane do państwa członkowskiego, aby mogło się z nimi zapoznać (w wypadku potencjalnego zagrożenia szkodą dla „stron zainteresowanych" uwagi zostają zanonimizowane) i udzielić odpowiedzi w terminie miesiąca (art. 6 ust. 2). Od momentu wszczęcia procedury dochodzenia Komisja może zażądać informacji od pozostałych państw członkowskich oraz przedsiębiorstw, co wymaga spełnienia warunków z art. 7. Zakończeniem czynności kontrolnych, a zarazem formalnego dochodzenia jest decyzja wydana przez Komisję. Może ona ustalać, że środek nie stanowi pomocy państwa albo może mieć charakter pozytywny (pomoc państwa zgodna z rynkiem wewnętrznym), albo warunkowy (deklaracja zgodności z rynkiem wewnętrznym obwarowana warunkami, wraz z potencjalną możliwością dalszego monitorowania środka, rozszerzoną względem art. 108 ust. 1 TFUE), albo negatywny (art. 9 ust. 2-5

48 Przepis ten, obecny również w rozporządzeniu 659/1999 uchylonym rozporządzeniem 2015/1589, wywodzi się z „orzecznictwa Lorenz”, zob. wyrok ETS w sprawie Lorenz, 120/73, ECLI:EU:C:1973:152, pkt 6.

49 Zob. Dyrekcja Generalna ds. Konkurencji, State Aid Manual of Procedures, Luksemburg 2013, sekcja 4.2.

50 Zob. wyrok ETS w sprawie Komisja v Francja, C-367/95, ECLI:EU:C:1998:154, pkt 38; wyrok TSUE w sprawie Mory v Komisja, C-33/14 P, ECLI:EU:C:2015:609, pkt 94. 
rozporządzenia 2015/1589). Jeśli pomoc państwa została przyznana, to za decyzją negatywną podąża decyzja o windykacji pomocy od beneficjentów wraz z odsetkami (art. 16). Stadium to, implikując również dużo większe wątpliwości Komisji co do środka, nie przewiduje (nominalnego) uznania pomocy państwa za zgodną z rynkiem wewnętrznym w obliczu bezczynności organu jak przy badaniu wstępnym (art. 4 ust. 6).

Na podjęcie rozstrzygnięcia kończącego formalną procedurę dochodzenia Komisja ma co do zasady osiemnaście miesięcy. W porównaniu z dwumiesięcznym badaniem wstępnym z jednej strony wskazuje to na większą zawiłość oceny dokonywanej w tej fazie postępowania, z drugiej zaś ujawnia kolejne korzyści, jakie stoją za wcześniejszym przygotowaniem badania wstępnego (przez prenotyfikację). Termin ten powinien być rozsądnie dostosowywany in concreto $^{51}$.

W procedurze dochodzenia uczestniczą nie tylko państwo i Komisja, lecz także „zainteresowane strony”, a zatem „którekolwiek Państwo Członkowskie oraz jakiekolwiek osoby, przedsiębiorstwa lub związki przedsiębiorstw, na których interesy może mieć wpływ przyznanie pomocy" (art. 1 lit. h). Zauważyć należy, że podmioty te są uprawnione do przedłożenia uwag po wszczęciu opisywanego stadium w terminie miesiąca (art. 24 ust. 1) ${ }^{52}$. O ile jednak państwo członkowskie może odpowiedzieć na przedstawione uwagi, ,zainteresowana strona” nie ma takiego prawa w stosunku do odpowiedzi państwa. Podmiotowi, który wystąpił w charakterze „strony zainteresowanej”, Komisja przesyła kopię decyzji kończącej postępowanie ${ }^{53}$.

Warto podkreślić też, że postępowanie może dotyczyć nielegalnej pomocy państwa (wdrożonej bez zatwierdzającej środek decyzji Komisji). Wówczas wszczęcie następuje zasadniczo z inicjatywy organu kontrolującego po powzięciu informacji z jakiegokolwiek źródła (art. 12 ust. 1). Postępowanie to charakteryzuje się przede wszystkim niewskazaniem granic temporalnych (art. 15 ust. 2). Poza tym Komisja może wydać decyzją nakazującą państwu członkowskiemu windykację pomocy przyznanej niezgodnie z prawem od beneficjenta tej pomocy (art. 16 i 17). W kontekście zaś kontroli istniejących programów pomocowych, w wypadku jej niezgodności z rynkiem wewnętrznym, Komisja proponuje ich zmianę czy wycofanie (art. 22), a gdy nie ma zgody państwa na wdrożenie tej propozycji, wszczyna się postępowanie opisane wcześniej (art. 23 ust. 2).

51 Zob. podtrzymany przez TSUE wyrok Sądu Pierwszej Instancji w sprawie Hiszpania v Komisja, T-461/13, ECLI:EU:T:2015:891, pkt 141.

52 Także do powtórnego zajęcia stanowisk, gdy dochodzi do istotnej zmiany przepisów w okresie między zgłoszeniem pomocy i wydaniem przez Komisję decyzji, zob. wyrok ETS w sprawie Komisja v Freistaat Sachsen, C-334/07 P, ECLI:EU:C:2008:709, pkt 56.

53 Zob. więcej P.W. Jessen et al., Regulating Competition in the EU, Alphen aan den Rijn 2016, s. 342-346. 
Należy dodać, że Komisja dąży do uproszczenia czy przyspieszenia procedur i zwiększenia przewidywalności rozstrzygnięćc ${ }^{54}$. Rezultaty te osiągane są przez: prenotyfikację $e^{55}$, grupowanie żądań informacji na etapie badania wstępnego i przesyłanie możliwie jednego, zbiorczego żądania ${ }^{56}$ oraz postulowanie starań, by wydać decyzję kończącą formalną procedurę dochodzenia nie później niż sześć miesięcy po przedłożeniu ostatniej informacji przez państwo członkowskie albo bezskutecznym upływie terminu na takie przedłożenie ${ }^{57}$. Jak powiedziano, przewidywalności przydaje też sprecyzowanie kryteriów kontroli opisanych wcześniej.

Właśnie te kryteria wraz z wnioskami badania sektorowego zebranymi w sprawozdaniu z 2016 roku stały się fundamentem niniejszego stanowiska Komisji w sprawie $\mathrm{MZW}^{58}$. Stanowisko to przerodziło się w rozporządzenie 2019/943, które zdefiniowało same mechanizmy w art. 2 pkt 22 jako środki tymczasowe mające na celu „zapewnienie osiągnięcia niezbędnego poziomu wystarczalności zasobów przez wynagradzanie dostępności zasobów, z wyłączeniem środków dotyczących usług pomocniczych lub zarządzania ograniczeniami przesyłowym". W kontekście MZW pośród najważniejszych zmian wprowadzonych tym aktem należy wymienić transgraniczną koordynację wskazywaną wcześniej przez literaturę jako brakujący element konstrukcji rynku ${ }^{59}$. Ponadto wprowadzono europejską ocenę wystarczalności zasobów i nadano priorytet reformom rynkowym. Mieści się to w podejściu „rynek na pierwszym miejscu”, jakie przyjęto do realizacji celów środowiskowych, jak też obniżenia cen energii elektrycznej oraz zapewnienia bezpieczeństwa jej dostaw.

\section{Koordynacja MZW — rozporządzenie 2019/943 w sprawie rynku wewnętrznego energii elektrycznej}

Schemat zawarty w rozporządzeniu 2019/943 rozpoczyna się od oceny wystarczalności zasobów, która jest przeprowadzana na poziomie europejskim, przy możliwej również ocenie uzupełniającej na poziomie krajowym — zależnie od uznania państwa członkowskiego. Ocena ta dotyczy ogólnej zdolności pokrycia

54 Zob. Unowocześnienie pomocy państwa, sekcja 2.3.

55 Zob. F. Mazzocchi, Overview of State Aid to Particular Sectors: State Aid and the Financial Crisis, [w:] Competition and State Aid..., s. 345.

56 Zob. Kodeks praktyk, s. 19.

57 Zob. ibidem, s. 22.

${ }^{58}$ Uzasadnienie projektu rozporządzenia Paramentu Europejskiego i Rady w sprawie rynku wewnętrznego energii elektrycznej, pkt 3. Ocena skutków, COM(2016) 861 final.

59 Zob. A. Bublitz et al., A survey on electricity market design: Insights from theory and real-world implementations of capacity remuneration mechanisms, „Energy Economics” 2019, nr 80, s. 1073; o zaletach koordynacji zob. M. Bucksteeg, S. Spiecker, Ch. Weber, Impact of Coordinated Capacity Mechanisms on the European Power Market, 2017, https://ssrn.com/abstract=2896686 (dostęp: 26.02.2020), s. 18. 
zapotrzebowania aktualnego oraz przyszłego, obejmując w wypadku oceny europejskiej okres dziesięciu lat (art. 23 ust. 1). Jest to analiza średno- i długoterminowa, która pozwala zidentyfikować obawy o wystarczalność zasobów. Przeprowadzona ocena na poziomie europejskim, jakkolwiek powinna dawać Komisji wgląd w wystarczalność zasobów, nie może naruszać prawa państwa członkowskiego do ustanowienia pożądanego poziomu wystarczalności (zob. pkt 46 preambuły). Ponadto art. 21 ust. 4 uzależnia wprowadzenie MZW od wykazania problemów z wystarczalnością zasobów przez ocenę europejską i (o ile została przeprowadzona) krajową. Należy wskazać ten wymóg jako wynik integrowania rynku energii elektrycznej na poziomie ponadnarodowym, gdyż nie pozwala na wprowadzenie mechanizmu, kiedy problem wystarczalności zasobów został wskazany jedynie przez ocenę krajową.

W wypadku zidentyfikowania zakłóceń regulacyjnych i niedoskonałości rynku państwo członkowskie w ramach pomocy państwa opracowuje i publikuje plan wdrożenia wraz z harmonogramem przyjmowania środków (art. 20 ust. 3). Plan wdrożenia zawierający właściwe z punktu widzenia państwa środki przedstawiany jest Komisji celem zaopiniowania, czy jest wystarczający do eliminacji zidentyfikowanych zakłóceń i niedoskonałości (ust. 4). Państwa mogą być wezwane do dokonania zmian w planach wdrożenia, a co roku publikują wyniki realizacji planu oraz monitorują jego stosowanie. Nawet po wydaniu przez Komisję późniejszej opinii o usunięciu zakłócenia czy niedoskonałości plany wciąż powinny być stosowane (art. 20 ust. 8) do osiągnięcia możliwie trwałych skutków regulacyjnych i rynkowych.

Komisja w czasie procedury prawodawczej podkreśliła wyraźnie, że opracowanie i publikacja planów wdrożenia dotyczących reformy rynku nie powoduje uszczerbku w jej wyłącznej kompetencji oceny zgodności środków (zwłaszcza MZW) stanowiących pomoc państwa zgodnie z art. 108 TFUE $^{60}$. Postępowanie z art. 20 ust. 5 rozporządzenia 2019/943 jest prawnie odmienne od postępowania w sprawie pomocy państwa. Opinia w sprawie planu wdrożenia ma bowiem za wyłączny przedmiot wystarczalność reform do eliminacji zakłóceń regulacyjnych i niedoskonałości rynku. I choć plan ten pozostaje w ramach procesu pomocy państwa, to należy wskazać, że ze względu na to szczególne kryterium „wystarczalności”, niezależnie od decyzji Komisji w sprawie zgodności środka z rynkiem wewnętrznym, mechanizmy nie mogą być wprowadzone przed wydaniem rzeczonej opinii przez Komisję (art. 21 ust. 5 rozporządzenia 2019/943). Co za tym też idzie opublikowanie programu wdrożenia nie zwalnia państwa członkowskiego z obowiązku zgłoszenia pomocy państwa, nałożonego art. 108 ust. 3 TFUE.

60 Zob. oświadczenie Komisji w sprawie planów wdrożenia reformy rynku z dnia 14 maja 2019 roku, 8737/19 ADD 1 REV 1, https:/data.consilium.europa.eu/doc/document/ST-8737-2019-ADD1-REV-1/en/pdf (dostęp: 26.02.2020). Stanowisko to prezentowane jest w samym rozporządzeniu 2019/943 (zob. pkt 47 preambuły oraz art. 21 ust. 1). 
Proces opiniowania, prawnie rozłączny z kontrolą środków stanowiących pomoc państwa (zarówno za sprawą podstawy prawnej, jak i kryterium), ma zarazem istotny wpływ na kształt stosowania mechanizmu. Zgodnie bowiem $\mathrm{z}$ art. 21 ust. 8 opiniowany plan wdrożenia ma być podstawą późniejszego wycofywania MZW lub zmniejszania zaangażowanych przez nie zdolności wytwórczych.

Przed wprowadzeniem MZW państwo członkowskie powinno też przeprowadzić kompleksowe badanie możliwego wpływu mechanizmu na sąsiadujące państwa członkowskie, konsultując co najmniej zarówno je, jak i „zainteresowane strony" w tych państwach (art. 21 ust. 2). Ma to na celu uniknięcie opisywanej niedoskonałości związanej z niekorzystnym oddziaływaniem mechanizmów na uczestników wzajemnie połączonego rynku.

Ocena konstrukcji mechanizmów, jakkolwiek nie została wyrażona explicite w rozporządzeniu 2019/943, powinna być dokonywana w ramach procesu badania pomocy państwa. Choć brakuje jednoznacznego włączenia jej do szeroko rozumianej procedury kontrolnej Komisji, pojawia się kilka argumentów, które popierają taki stan rzeczy: podobieństwo nowych zasad konstrukcji do określonych w Wytycznych 2014-2020, tożsamość podmiotu (Komisji) rozpoznającego sprawę, istniejący w obu wypadkach zasadniczy obowiązek zgłaszania MZW przed ich wprowadzeniem. Ponadto takie rozumowanie popiera ekonomia proceduralna, która w wypadku zmian sytuacji prawnej czy faktycznej w czasie trwania badania (jak zmiana samego mechanizmu przez państwo członkowskie) nakazywałaby raczej prowadzić te postępowania jako objęte jedną procedurą. Należy też wnioskować, że art. 21 ust 8, nazywając czynność Komisji „,zatwierdzeniem” mechanizmu, dotyczy decyzji o zgodności środka z rynkiem wewnętrznym, wydawanej w procesie pomocy państwa.

\section{Konkluzje}

Rozporządzenie 2019/943 uzależniło wprowadzenie MZW od zaopiniowania przez Komisję planu wdrożenia reform rynku, wskazując przy tym, że mechanizmy mogą być wykorzystane jedynie jako ostateczność. Poza tym właśnie na podstawie tego planu stopniowo wycofuje się lub ogranicza zastosowanie mechanizmów, co wskazuje na pośrednią, choć relewantną (wobec wprowadzenia i stosowania MZW) rolę postępowania, w którym Komisja rozstrzyga w drodze opinii. Oprócz tej zmiany stawiającej dodatkowe wymagania względem państwa wprowadzającego MZW rozporządzeniem 2019/943 zredefiniowano też zasady oceny środków w postępowaniu kontrolnym, nadając im moc wiążącą zwiększenia skuteczności i spójności stosowania prawa pomocy państwa.

Nowe zasady konstrukcji mechanizmów wykorzystywane do oceny w postępowaniu kontrolnym art. 108 TFUE uczynią je przy tym bardziej szczegółowym i restrykcyjnym względem dotychczasowego opartego na zasadach oceny z Wy- 
tycznych 2014-2020. Zarazem wydaje się, że na obecnym etapie rozwoju prawa unijnego trudno konstruować MZW, które nie byłyby pomocą państwa, a tym samym nie podlegały tej kontroli. Wskazane w sprawozdaniu z 2016 roku kryteria, które uprawdopodabniają pomocowy charakter mechanizmów, skłaniają się bowiem nie tylko do całkowitego wyeliminowania udziału państwa w ustanawianiu środków, lecz także ustanawiają wymóg na dostawcach zdolności wytwórczych, by powstrzymali się od uczestnictwa w rynku energii.

Wszakże wykorzystanie tych samych, w całości wiążących, kryteriów do badania MZW ma ogromne znaczenie dla pełnej spójności regulacji rynku energii i stosowania prawa pomocy państwa, a ponadto zapewnienia bezpieczeństwa dostaw energii. Prowadzić również może do pożądanej jedności lub podobieństwa ocen w postępowaniu kontrolnym i przewidywalnych rozstrzygnięć. W rezultacie powinno to skutkować większą koordynacją między państwami członkowskimi. Koordynacja ta wzmacniana jest też uprzednią europejską oceną adekwatności i konsultowaniem planowanych MZW z sąsiadującymi państwami członkowskimi, bez których nie może dojść do wprowadzenia mechanizmów. Jako zapewniająca spójność i koordynująca powinna być upatrywana funkcja pełniona przez sądy Unii, zwłaszcza w zakresie art. 263 TFUE. W konsekwencji dokonywanej przez nie kontroli legalności dochodzi do jeszcze dalszej standaryzacji postępowania prowadzonego przez Komisję, co może tworzyć gwarancję zgodności proceduralnej istotnej nie tylko dla państw członkowskich, lecz także innych uczestników postępowania $^{61}$.

Wciąż istnieje jednak pytanie, czy względy ekonomicznej wagi MZW uzasadniają dostatecznie tak drobiazgową regulację. Podobnie można rozważać, czy postępowanie kontrolne i mające na mechanizmy pośredni wpływ opiniowanie planu wdrożenia tworzą większy ciężar dla państw członkowskich, czy raczej w obecnym kształcie są ograniczeniem dla Komisji.

\section{Bibliografia}

\section{Opracowania}

Bublitz A. et al., A survey on electricity market design: Insights from theory and real-world implementations of capacity remuneration mechanisms, „Energy Economics” 2019, nr 80.

Bucksteeg M., Spiecker S., Weber Ch., Impact of Coordinated Capacity Mechanisms on the European Power Market, 2017, https://ssrn.com/abstract=2896686.

Capeda M., Assessing cross-border integration of capacity mechanisms in coupled electricity markets, „Energy Policy” 2018, nr 119.

Dyrekcja Generalna ds. Konkurencji, State Aid Manual of Procedures, Luksemburg 2013.

${ }^{61}$ Zob. wyrok TSUE w sprawie Tempus Energy, T-793/14, ECLI:EU:T:2018:790, zwłaszcza pkt 93, 98, 113-114, 203, 213. 
González-Díaz F.E., EU Policy on Capacity Mechanisms, [w:] Capacity Mechanisms in the EU Energy Market: law, politics and economics, red. L. Hancher, A. de Hauteclocque, M. Sadowska, Oxford 2015.

Hancher L., Capacity Mechanisms and State Aid Control, [w:] Capacity Mechanisms in the EU Energy Market: law, politics and economics, red. L. Hancher, A. de Hauteclocque, M. Sadowska, Oxford 2015.

Hancher L., Riechmann Ch., Capacity Mechanisms and Auctions, [w:] State aid and the energy sector, red. L. Hancher, A. de Hauteclocque, F.M. Salerno, Oxford 2018.

Hary N., Rious V., Saguan M., The electricity generation adequacy problem: Assessing dynamic effects of capacity remuneration mechanisms, „Energy Policy” 2016, nr 91.

Horubski K., Kieres L., Kocowski T., Szydło M., Żurawik A., Podstawowe pojęcia publicznego prawa gospodarczego, [w:] System prawa administracyjnego, t. 8a. Prawo publiczne gospodarcze, red. Hauser R. et al., Warszawa 2018.

Huhta K., Capacity Mechanisms in EU Energy Law, Alphen aan den Rijn 2019.

Jessen P.W. et al., Regulating Competition in the EU, Alphen aan den Rijn 2016.

Mazzocchi F., Overview of State Aid to Particular Sectors: State Aid and the Financial Crisis, [w:] Competition and State Aid - An Analysis of the EU Practice, red. A. Santa Maria, Alphen aan den Rijn 2015.

Mazzocchi F., The Procedures before the Commission, [w:] Competition and State Aid - An Analysis of the EU Practice, red. A. Santa Maria, Alphen aan den Rijn 2015.

Nicolaides P. et al., The Concept of State Aid, [w:] iidem, State Aid Policy in the European Community. Principles and Practice, Alphen aan den Rijn 2008.

Righini E., González Fernández J.C., Capacity Mechanisms and State Aid: Between PSOs, Market Liberalisation, and Security of Supply, „Journal of European Competition Law \& Practice” 2016, nr 7 (10).

Tennbakk B. et al., Framework for cross-border participation in capacity mechanisms, Luksemburg 2014.

\section{Źródła}

Decyzja Komisji w sprawie Hiszpania, preferencyjne wykorzystywanie na rzecz elektrowni używających rodzimego węgla, N178/2010 (2010), C(2010)4499.

Decyzja Komisji w sprawie Irlandia, obowiązek użyteczności publicznej w związku z nową zdolnością wytwórczą energii elektrycznej dla bezpieczeństwa dostaw, N475/2003 (2003), C(2003)4488fin.

Decyzja Komisji w sprawie Łotwa, oferta przetargowa dotycząca pomocy dla nowych zdolności wytwórczych energii elektrycznej N675/2009 (2010), C(2010)4146.

Decyzja Komisji w sprawie Stowenia, wsparcie produkcji energii elektrycznej z odnawialnych źródeł energii i w istalacjach kogeneracyjnych, N354/2009 (2009), C(2009)8353.

Komunikat Komisji Kodeks najlepszych praktyk dotyczacych przebiegu postępowania w zakresie kontroli pomocy państwa, C(2018) 4412 final, EUR-Lex 52018XC0719(01), sekcja 6.2;

Komunikat Komisji - Unowocześnienie unijnej polityki $w$ dziedzinie pomocy państwa, COM(2012) 209 final, EUR-Lex 52012DC0209.

Komunikat Komisji - Wytyczne w sprawie pomocy państwa na ochronę środowiska i cele związane z energią w latach 2014-2020, EUR-Lex 52014XC0628(01).

Opinia Rzecznika Generalnego Camposa Sáncheza-Bordony w sprawie Georgsmarienhütte GmbH $v$ RFN, C-135/16, ECLI:EU:C:2018:120.

Opinia Rzecznika Generalnego Evgeniego Tancheva w sprawie Komisja v Gmina Miasto Gdynia i Port Lotniczy Gdynia Kosakowo, C-56/18 P, ECLI:EU:C:2019:569.

Oświadczenie Komisji w sprawie planów wdrożenia reformy rynku z dnia 14 maja 2019 roku, 8737/19 ADD 1 REV 1, https://data.consilium.europa.eu/doc/document/ST-8737-2019-ADD-1-REV-1/en/pdf.

Studenckie Prace Prawnicze, Administratywistyczne

i Ekonomiczne 33, 2020

(C) for this edition by CNS 
Projekt rozporządzenia Parlamentu Europejskiego i Rady w sprawie rynku wewnętrznego energii elektrycznej, COM(2016) 861 final, EUR-Lex 52016PC0861.

Protokół (nr 26) w sprawie usług świadczonych w interesie ogólnym (Dz. Urz. UE C 202 z dnia 7 czerwca 2016).

Rozporządzenie Komisji Nr 1407/2013 z dnia 18 grudnia 2013 roku w sprawie stosowania art. 107 i 108 TFUE do pomocy de minimis (Dz. Urz. UE L 352 z dnia 24 grudnia 2013).

Rozporządzenie Komisji Nr 651/2014 z dnia 17 czerwca 2014 roku uznające niektóre rodzaje pomocy za zgodne z rynkiem wewnętrznym w zastosowaniu art. 107 i 108 TFUE (Dz. Urz. UE L 187 z dnia 26 czerwca 2014).

Rozporządzenia Parlamentu Europejskiego i Rady (UE) 2019/943 z dnia 5 czerwca 2019 roku w sprawie rynku wewnętrznego energii elektrycznej (Dz. Urz. UE L 158 z dnia 14 czerwca 2019).

Rozporządzenie Rady Europejskiej 2015/1589 ustanawiające szczegółowe zasady stosowania art. 108 TFUE (Dz. Urz. UE L 248 z dnia 24 września 2015).

Sprawozdanie końcowe Komisji z badania sektorowego dotyczącego mechanizmów zapewniających zdolności wytwórcze, COM(2016) 752 final, EUR-Lex 52016DC0752.

Traktat o funkcjonowaniu Unii Europejskiej (Dz. Urz. UE C 202 z dnia 7 czerwca 2016).

\section{Orzecznictwo}

Wyrok ETS w sprawie Lorenz, 120/73, ECLI:EU:C:1973:152.

Wyrok ETS w sprawach Sloman Neptun, C-72/91 i C-73/91, ECLI:EU:C:1993:97.

Wyrok ETS w sprawie Komisja v Francja, C-367/95, ECLI:EU:C:1998:154.

Wyrok ETS w sprawie Ecotrade, C-200/97, ECLI:EU:C:1998:579.

Wyrok ETS w sprawie Hiszpania $v$ Komisja, C-342/96, CLI:EU:C:1999:210.

Wyrok ETS w sprawie Niemcy v Komisja, C-156/98, ECLI:EU:C:2000:467.

Wyrok ETS w sprawie PreussenElektra AG v Schhleswag AG, C-379/98, ECLI:EU:C:2001:160.

Wyrok ETS w sprawie Adria-Wien Pipeline i Wietersdorfer v Peggauer Zementwerke, C-143/99, ECLI:EU:C:2001:598.

Wyrok ETS w sprawie Francja v Komisja (Stardust), C-482/99, ECLI:EU:C:2002:294.

Wyrok ETS w sprawie Francja v Komisja, C-482/99, ECLI:EU:C:2002:294.

Wyrok ETS w sprawie Altmark Trans, C-280/00, ECLI:EU:C:2003:415.

Wyrok ETS w sprawie Heiser, C-172/03, ECLI:EU:C:2005:130.

Wyrok ETS w sprawie Essent Netwerk Noord, C-206/06, ECLI:EU:C:2008:413.

Wyrok ETS w sprawie Komisja v Freistaat Sachsen, C-334/07 P, ECLI:EU:C:2008:709.

Wyrok Sądu Pierwszej Instancji w sprawie Technische Glaswerke Ilmenau v Komisja, T-198/01, ECLI:EU:T:2004:222.

Wyrok Sądu w sprawie Hiszpania v Komisja, T-461/13, ECLI:EU:T:2015:891.

Wyrok TSUE w sprawie Technische Glaswerke Ilmenau, C-139/07 P, ECLI:EU:C:2010:376.

Wyrok TSUE w sprawach Bouygues, C-399/10 P i C-401/10 P, ECLI:EU:C:2013:175.

Wyrok TSUE w sprawie Association Vent De Colère! i in., C-262/12, ECLI:EU:C:2013:851.

Wyrok TSUE w sprawie Mory v Komisja, C-33/14 P, ECLI:EU:C:2015:609.

Wyrok TSUE w sprawie Komisja $v$ World Duty Free Group i in., C-20/15 P i C-21/15 P, ECLI:EU:C:2016: 981.

Wyrok TSUE w sprawie ENEA, C-329/15, ECLI:EU:C:2017:671.

Wyrok TSUE w sprawie Viasat Broadcasting UK v Komisja, C-660/15 P, ECLI:EU:C:2017:178.

Wyrok TSUE w sprawie Komisja v FIH, C-579/16 P, ECLI:EU:C:2018:159.

Wyrok TSUE w sprawie Tempus Energy, T-793/14, ECLI:EU:T:2018:790.

Wyrok TSUE w sprawie Niemcy $v$ Komisja, C-405/16 P, ECLI:EU:C:2019:268.

Wyrok TSUE w sprawie $A B$,Achema” v VKEKK, C-706/17, ECLI:EU:C:2019:407.

Studenckie Prace Prawnicze, Administratywistyczne

i Ekonomiczne 33, 2020

(C) for this edition by CNS 